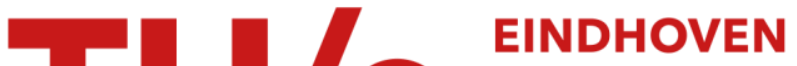 UNIVERSITY OF TECHNOLOGY
}

\section{Effects of instruction, visual imagery and educational background on process control performance}

\section{Citation for published version (APA):}

Landeweerd, J. A., Seegers, H. J. J. L., \& Praagman, J. (1981). Effects of instruction, visual imagery and educational background on process control performance. Ergonomics, 24(2), 133-141.

\section{Document status and date:}

Published: 01/01/1981

\section{Document Version:}

Publisher's PDF, also known as Version of Record (includes final page, issue and volume numbers)

\section{Please check the document version of this publication:}

- A submitted manuscript is the version of the article upon submission and before peer-review. There can be important differences between the submitted version and the official published version of record. People interested in the research are advised to contact the author for the final version of the publication, or visit the $\mathrm{DOI}$ to the publisher's website.

- The final author version and the galley proof are versions of the publication after peer review.

- The final published version features the final layout of the paper including the volume, issue and page numbers.

Link to publication

\section{General rights}

Copyright and moral rights for the publications made accessible in the public portal are retained by the authors and/or other copyright owners and it is a condition of accessing publications that users recognise and abide by the legal requirements associated with these rights.

- Users may download and print one copy of any publication from the public portal for the purpose of private study or research.

- You may not further distribute the material or use it for any profit-making activity or commercial gain

- You may freely distribute the URL identifying the publication in the public portal.

If the publication is distributed under the terms of Article 25fa of the Dutch Copyright Act, indicated by the "Taverne" license above, please follow below link for the End User Agreement:

www.tue.nl/taverne

Take down policy

If you believe that this document breaches copyright please contact us at:

openaccess@tue.nl

providing details and we will investigate your claim. 


\title{
Effects of instruction, visual imagery and educational background on process control performance
}

\author{
By J. A. Landeweerd, H. J. J. L. Seegers and J. Praagman \\ Department of Industrial Engineering, Eindhoven University of Technology, \\ Eindhoven, The Netherlands
}

\begin{abstract}
The effects of instruction, vividness of visual imagery and education were evaluated on operator control performance on a relatively complex process simulator. Thirtytwo subjects took part. Analysis of variance of the data indicated a significant effect due to instruction. No significant effects were found for vividness of visual imagery or educational background, nor any significant interactions. A significant learning effect was shown to exist for one of the levels of instruction, namely the group with process information. The group with only input-output information did not show any learning effect over the three experimental trials.
\end{abstract}

\section{Introduction}

The effects were studied of three variables on the control performance of process operators:

(a) Instruction. In operator training a recurring problem concerns the amount and form of information to be given about the process. Crossman and Cooke (1962, see also 1974) and Landeweerd (1968, see also Kragt and Landeweerd 1974) report experiments with relatively simple systems, in which response time constants have been inserted to make the situation more comparable with realistic process control. The results cast some doubt on the usefulness of extensive information about the chemical and physical details of the process. In Kragt and Landeweerd (1974), it is argued that this might be due to rather complex internal representations of the process being built up by the subjects for the task at hand; for relatively simple tasks, such as the ones used, a routine model of the process might be sufficient. With more complex, and more realistic processes, however, more and other forms of information might be necessary.

Brigham and Laios (1975) report an experiment with such a system. Their most important result appears to be that information on the structure and dynamics of the plant before the task, coupled with information on intermediate processes during the task probably results in the best performance. In their view, it enables the subject to form an anticipatory model of the process. We were interested to know whether an even more complex system than the one used by Brigham and Laios would give comparable results. In particular, we wanted to investigate whether information about the relations between system input and output without reference to intermediate processes (type I information) would lead to worse control performance than information about these relations with added information on the intermediate processes (type II information). The two situations are represented in figure 1.

(b) Visual imagery. In cognitive psychology generally, two modes of mental representation of reality are distinguished (Paivio 1971, Norman and Rumelhart 1975, Landeweerd 1978, 1979): a more verbal or abstract mode and a more visual or concrete mode. This distinction, however, is sometimes criticized (Pylyshyn 1973). We wanted to explore the role of vividness of visual imagery when controlling a slow-response system, keeping in mind that visual images seem to play an important part in more concrete 

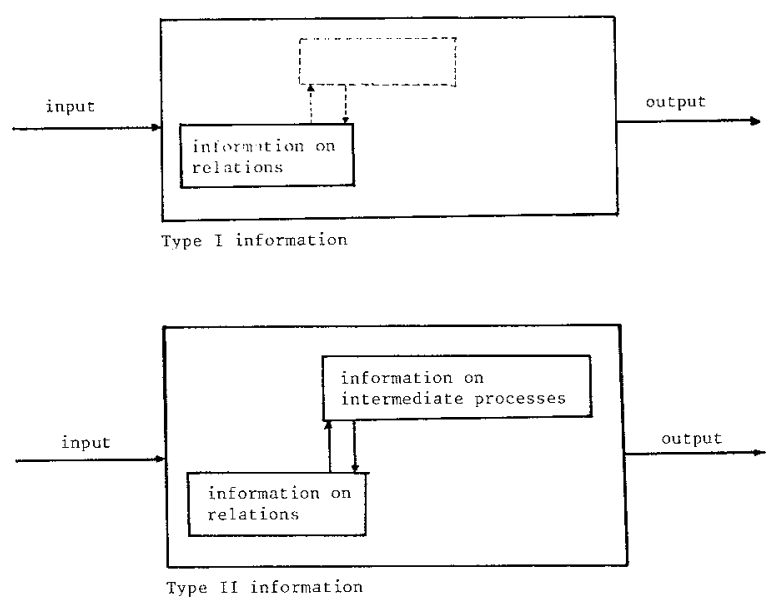

Figure 1. Type I and type II information.

tasks (Paivio 1971, Denis 1974). If the task for the subject could be interpreted as mainly a concrete one, better performance is to be expected in subjects with a high score on vividness of visual imagery.

(c) Education. Because of the possible consequences of this variable for generalizing the results of experiments with students to other populations (especially operators and operator trainees), it seemed to be interesting to explore its role. We wanted to know whether subjects with a higher science oriented educational background (future technical students) would perform differently from subjects with a lower technical educational background. For this reason the variable 'education' was included in the experiment. The model of investigation then was as follows (figure 2).

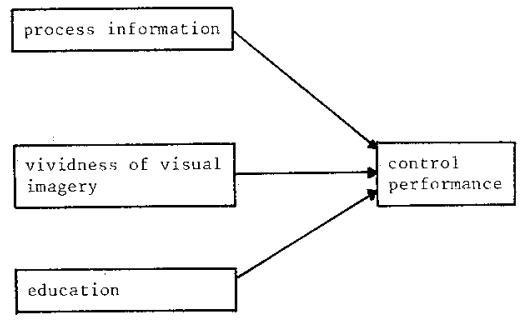

Figure 2. Model of the investigation.

When confronting the subject with a number of trials, a learning effect may be expected if the subjects receive knowledge of results. So in subjects who did not have the opportunity to gain insight into the process itself, only a slight learning effect or no effect at all may be expected, in contrast with the well-informed group. The latter group is able to give a sensible interpretation of the feedback they receive from their control actions. They not only know what went wrong but also why and so they may correct their actions. In other words, they can learn from their results and their control performance may therefore improve over a number of trials. 


\section{Hypotheses}

Four hypotheses were formulated:

(a) Subjects with information on intermediate processes (process information) will perform better on a process control task than subjects without this information.

(b) Subjects with a vivid visual imagery will perform better than subjects with a less vivid visual imagery.

(c) Subjects with a higher science oriented educational background will perform better than subjects with a lower technical background.

(d) In contrast to subjects without information on intermediate processes, subjects who do possess this information will show an improvement in control performance over a number of trials.

\section{Method and procedure}

3.1. Equipment The process used for this experiment was a simulated single distillation column. The simulation was based on a model of a real column at the DSM Chemical Industries; this model was implemented on a DEC PDP 11/40 minicomputer. Experimental data were stored and analysed by the computer. In the simulated process, a two-component feed-flow is distilled into a top-product and a bottomproduct. The subjects had to optimize the quality of both the top- and the bottomproduct.

In the experiment the subject had two degrees of freedom with which to achieve the system's goal: the setpoint setting of reflux flow, and of temperature. These two parameters have a great influence on the concentration and flows of the top- and bottom-product. The time lags between setpoint and output-concentration are up to $5 \mathrm{~min}$ and rising times are up to half an hour.

The experiment was carried out in a simulated control room at a control panel with 14 instruments. For more details on the equipment, see Paternotte and Verhagen (1979).

\subsection{Independent variables}

The three independent variables were specified as follows:

(1) Instruction. The two levels of this variable differed in the type of information given:

(a) Type I information. This is limited to information about the three most important aspects of the input-output relations, without giving details of the process itselif:

(i) direction, i.e. information about the directional influence of turning the knobs for reflux and temperature on top- and bottom quality;

(ii) amount, i.e. information about the amount of change to be expected from actions at the control knobs;

(iii) interaction, i.e. the mutual influence of the two action possibilities.

(b) Type II information. This concerns ample information on the process itself in addition to the type I information. The process information was given by means of a programmed instruction text (see $\S 3.6$.). 
(2) Visual imagery. The vividness of visual imagery was measured by the Marks V.V.I.Q. (Vividness of Visual Imagery Questionnaire) (see Marks 1973). Two levels were distinguished: low vividness (LoVi), i.e. scores below the median, and high vividness (HiVi), i.e. scores above the median.

(3) Education. Two levels of education were distinguished: a lower technical education (LoEd), in this case pupils from a polytechnic school (a sort of vocational school); and a higher educational level (future technical university students from a sience oriented secondary school).

\subsection{Dependent variable}

The dependent variable was the control performance of the subject. This was measured by the sum of integrals of the absolute deviation scores of the two concentration values $e_{\text {top }}$ and $e_{\text {bottom }}$, which is called the E-score (error score).

\subsection{Subjects}

The subjects were 32 male pupils, with an average age about $17 ; 16$ of them were from the secondary school, and the other 16 were pupils from the polytechnic.

From each educational level a large group of pupils was tested and selected on high and low visual imagery. Thus half of each group of 16 subjects scored below the median, and half of them scored above the median. They were then assigned at random to the two levels of the first experimental variable (i.e. type of information).

\subsection{Experimental design}

The experimental design is presented in figure 3. The experimental design involves four subjects per cell and requires a three-way analysis of variance.

\begin{tabular}{lllllll}
\hline & \multicolumn{2}{c}{ LoEd } & & \multicolumn{2}{c}{ HiEd } \\
\cline { 6 - 6 } \cline { 5 - 6 } & LoVi & HiVi & & LoVi & HiVi \\
\hline Type I info & E-score & E-score & & E-score & E-score \\
Type II info & E-score & E-score & & E-score & & E-score \\
\hline
\end{tabular}

Figure 3. Experimental design.

\subsection{Instruction and task}

In figure 4 a schematic overview of the procedure is given.

(a) General introduction. All the subjects first received a general introduction on the research project and the experiment in which they were to participate.

(b) Programmed instruction. Only the group that received type II information was instructed about the process. The branched programmed instruction text designed for this purpose contained extensive information about process and equipment. The study of this text took about 2 hours.

(c) Description of panel. Both the type I and the type II groups received a written description of the panel, containing verbal and pictorial information about the equipment, especially the instruments to be used. The process itself was not described in any way. 


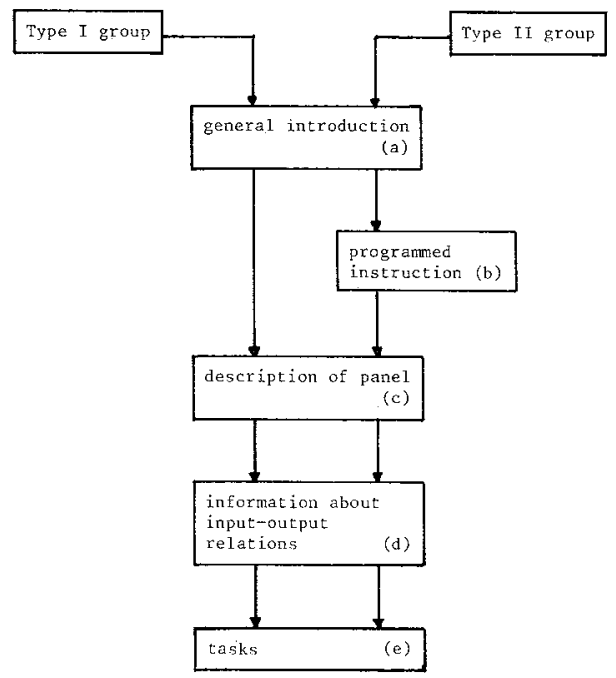

Figure 4. Procedure.

(d) Input-output information. This information was given by means of a video-tape; the control aspects of 'direction', 'amount' and 'interaction' were emphasized.

(e) Task. The task for the subjects was to bring the top and bottom concentration to the required values and attempt to keep them there. There were three 1 hour trials. The first two trials were considered to be typically learning trials. Only the scores on the third trial were used for the analysis of variance. In testing for the learning effect, the scores on all three trials were used.

\subsection{Control performance}

\section{Results}

The average results for the third trial are shown in table 1 . Note that these are error scores, so the lower the score the better the performance. Table 2 gives results of the analysis of variance.

Only 'type of information' had a significant $(\alpha=0.05)$ main effect, so we may draw the following conclusions:

(1) The subjects who received type II information (including process information) performed significantly better on trial 3 than those who received type I information only. (The average score of the first-mentioned group was 23.1, that of the second $38 \cdot 3$ ).

Table 1. Average error scores (four observations per cell).

\begin{tabular}{|c|c|c|c|c|c|}
\hline \multirow[b]{3}{*}{ Imagery } & & \multicolumn{4}{|c|}{ Education } \\
\hline & & \multicolumn{2}{|c|}{ LoEd } & \multicolumn{2}{|c|}{ HiEd } \\
\hline & & LoVi & $\mathrm{HiVi}$ & LoVi & $\mathrm{HiVi}$ \\
\hline \multirow[t]{2}{*}{ Information } & type I & $39 \cdot 3$ & $51 \cdot 4$ & $23 \cdot 7$ & 38.9 \\
\hline & type II & $26 \cdot 6$ & 17.9 & $20 \cdot 4$ & $27 \cdot 6$ \\
\hline
\end{tabular}


Table 2. Analysis of variance of results of third trial.

\begin{tabular}{lrrrrr}
\hline Source of variation & & \multicolumn{1}{c}{ SS } & df & \multicolumn{1}{c}{ MS } & \multicolumn{1}{c}{$F$} \\
\hline Type of information & $(A)$ & $1839 \cdot 19$ & 1 & $1839 \cdot 19$ & $6.33(p<0.05)$ \\
Vividness & $(B)$ & 338.01 & 1 & 388.01 & $1 \cdot 16($ n.s. $)$ \\
Educational level & $(C)$ & 302.57 & 1 & 302.57 & $1 \cdot 04$ (n.s.) \\
$A \times B$ & & $414 \cdot 72$ & 1 & 414.72 & $1 \cdot 43$ (n.s.) \\
$A \times C$ & & 492.98 & 1 & 492.98 & $1 \cdot 70$ (n.s.) \\
$B \times C$ & 183.35 & 1 & 183.35 & 0.63 (n.s.) \\
Residual & 7266.43 & 25 & 290.66 & \\
\hline
\end{tabular}

(2) Educational level and vividness of visual imagery did not have a significant effect on the control performance.

(3) No significant interactions were found.

\subsection{Learning effect}

The data concerning the learning effect (scores on all three trials) are presented in table 3 and figure 5. Only the 'type of information' factor was used in this analysis, because we expected that only this factor would influence learning performance (see hypothesis $(d)$ ) and because the other two factors did not show an effect on control performance.

Table 3. Average error scores on three trials.

\begin{tabular}{llccc}
\hline & & Trial 1 & Trial 2 & Trial 3 \\
\hline \multirow{2}{*}{ Information } & type I & $39 \cdot 3$ & $34 \cdot 9$ & $38 \cdot 3$ \\
& type II & $41 \cdot 5$ & $30 \cdot 6$ & $23 \cdot 1$ \\
\hline
\end{tabular}

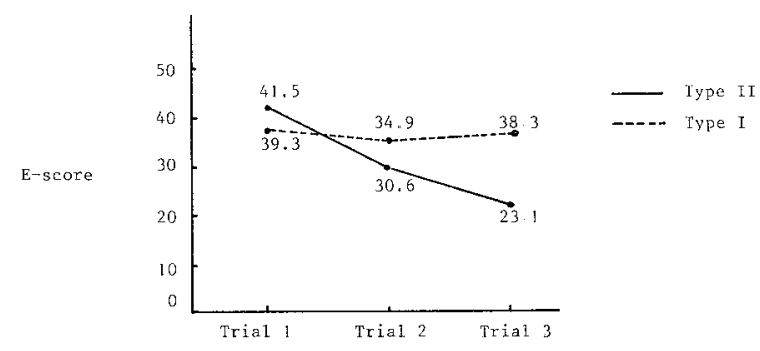

Figure 5. The scores of the type I and type II groups on the three trials.

Table 4 gives the results of an analysis of variance for each type of information group separately. (Both are two-way analyses with subjects as a blocking factor.)

\subsection{Conclusions}

(1) The results for both groups were consistent with the hypotheses (table 3). Also, the analysis of variance showed that the learning effect for the type II group was significant. 
Table 4.

(a) Analysis of variance for type I information group.

\begin{tabular}{lrrrl}
\hline Source of variation & \multicolumn{1}{c}{ SS } & df & \multicolumn{1}{c}{ MS } & $F$ \\
\hline Trials & 247.80 & 2 & 123.9 & 0.68 (n.s.) \\
Blocks (persons) & $6968 \cdot 42$ & 15 & & \\
Residual & $5481 \cdot 14$ & 30 & 182.7 & \\
\hline
\end{tabular}

(b) Analysis of variance for type II information group.

\begin{tabular}{lrrrl}
\hline Source of variation & \multicolumn{1}{c}{ SS } & df & MS & \multicolumn{1}{c}{$F$} \\
\hline Trials & $3276 \cdot 91$ & 2 & $1638 \cdot 46$ & $4 \cdot 70(p<0 \cdot 05)$ \\
Linear trend & $2690 \cdot 11$ & 1 & $2690 \cdot 11$ & $7 \cdot 71(p<0 \cdot 01)$ \\
Deviation from linearity & $586 \cdot 80$ & 1 & & \\
Blocks (persons) & $5648 \cdot 84$ & 15 & & \\
Residual & $10468 \cdot 78$ & 30 & 348.96 & \\
\hline
\end{tabular}

(2) To obtain more insight into the learning performance for the type II group, the between trials SS was partitioned into a part due to a linear trend and a part due to a deviation from linearity. The partition shows that the linear curve fitted our data rather well. This indicates an improvement in control performance of about the same magnitude in both the second and third trial of the type II group. This trend is not expected to continue in further trials, because of the well-known phenomenon of the learning plateau.

\section{Discussion}

(1) We found that information about the process itself had a positive effect on performance. This confirms the results of Brigham and Laios (1975) but it contrasts with the results of Landeweerd (1968, see also Kragt and Landeweerd 1974). Our process was a realistic simulation of an existing distillation column and as such the effects of control inputs on the outputs as well as the interactions between these inputs were quite complex. In such cases information about the process is apparently more effective than information about input-output relations only. The internal representation of the process must contain information that renders the relations understandable, so that adequate strategies can be formed. The interpretation given here also explains the significant learning effect in the group with type II information. They may improve their performance because they can give a sensible interpretation of the feedback they receive while controlling. Only this group can say why things did or did not go wrong. From interviews held after the experimental trials (these are not reported here), it appeared that the type II group did indeed understand the feedback better and could use it for upgrading their performance during the next trial.

(2) Our second hypothesis was not confirmed. Subjects with a high score on the V.V.I.Q. did not perform better than subjects with a low score. In fact, the actual average performance of the HiVi-group was worse than that of the LoVi-group (average HiVi-error score was $33 \cdot 9$, average LoVi-error score was $27 \cdot 5$ ). The task may in fact be much less concrete than originally assumed. It might even be a rather abstract task: relations between process variables have to be understood and examined, 
especially with regard to the effects of different control actions on the crucial output variables. This confirms the findings of Landeweerd $(1978,1979)$, who found that insight into the functioning of the process, i.e. in 'what-leads-to-what relations' correlated with control performance while a more visual image of process structure did not. However, it did correlate with the quality of search strategies into the causes of disturbances.

A typology of control tasks (concrete versus abstract; calling for control actions versus calling for diagnosis) may lead to a better insight into the question of what kind of internal representation would be most appropriate under various conditions.

Les effets des consignes, de la vivacité de l'imagerie visuelle et du niveau d'instruction ont été déterminés à partir des performances sur des commandes dans une tâche de simulation d'un processus complexe. Trente-déux sujets ont participé à l'expérience. L'analyse de la variance a fait apparaître un effet significatif lié aux consignes.

On n'a pas observé d'effets, ni d'interactions significatifs liés à la vivacité de l'imagerie visuelle ou au niveau d'instruction. Pour l'un des niveaux d'instruction, c'est-à-dire pour le groupe ayant à traiter de l'information, on a observé un effet significatif de l'apprentissage. Dans le groupe qui disposait uniquement de l'information entrée-sortie, on n'a pas observé d'effet d'apprentissage au cours des trois séquences expérimentales.

Die Auswirkungen von Unterweisung, visuellem Vorstellungsvermögen und Ausbildung auf das Überwachungsverhalten eines Maschinisten wurden mit einem relativ komplexen Prozeßsimulator an 32 Versuchspersonen überprüft. Die Varianzanalyse der Daten zeigte eine signifikante Auswirkung der Unterweisung. Weder wurden signifikante Auswirkungen des visuellen Vorstellungsvermögens oder der Ausbildung gefunden, noch signifikante Wechselwirkungen. Ein signifikanter Lerneffekt konnte für das Unterweisungsniveau der Gruppe mit Prozeßinformation nachgewiesen werden. Die Gruppe mit nur Input-OutputInformation zeigte während der drei Versuche keine Lerneffekte.

\section{References}

BRIGHAM, F. R., and LAIOS, L., 1975, Operator performance in the control of a laboratory process plant. Ergonomics, 18, 58-66.

Crossman, E. R. F. W., 1960, Automation and Skill. D.S.I.R., Problems of Progress in Industry No. 9 (London: H.M.S.O.). Extract in: 1974, The Human Operator in Process Control (Edited by E. Edwards and F. P. LeEs) (London: Taylor \& Francis LTD).

Crossman, E. R. F. W., and Cookf, J. E., 1962, Manual control of slow-response systems. International Congress on Human Factors in Electronics, California.

Crossman, E. R. F. W., and CoOKE, J. E., 1974, Manual control of slow-response systems. In The Human Operator in Process Control (Edited by E. EDwards and F. P. LEEs) (London: TAYLOR \& FRANCIS LTD).

DENIS, M., 1974, Portée et limites des effects de la représentation imagée sur la mémorisation de materiels significatifs simples. Ph.D. Thesis, Université de Paris.

Kragt, H., and LANDEWEERd, J. A., 1974, Mental skills in process control. In The Human Operator in Process Control (Edited by E. Edwards and F. P. LeEs) (London: TAYLor \& FRANCIS LTD).

Kragt, H., LANDEWEERD, J. A., and DE LeeuW, A. C. J., 1973, On the concept of mental model in the human control of production systems. Manufacturing Systems, 2, 3-14.

LANDEWEERD, J. A., 1968, The effect of instruction on performance when controlling a slowresponse system (in Dutch). M.Sc. Thesis, Free University, Amsterdam.

LANDEWEERD, J. A., 1978, Internal representation of a process by operator trainees. Ph.D. Thesis, University of Technology, Eindhoven (in Dutch; with summary in English).

LANDEWEERD, J. A., 1979, Internal representation of a process, fault diagnosis and fault correction. Ergonomics, 22, 1343-1351.

MARKs, D. R., 1973, Visual imagery differences in the recall of pictures. British Journal of Psychology, 1, 17-24. 
Norman, D. A., and Rumelhart, D. E., 1975, Exploration in Cognition (San Francisco: FREEMAN).

Parvio, A., 1971, Imagery and Verbal Processes (New York: HolT).

Paternotte, P. H., and Verhagen, L. H. J. M., 1979, Human operator research with a simulated distillation process. Ergonomics, 22, 19-28.

PYlyshyn, Z. W., 1973, What the mind's eye tells the mind's brain; a critique of mental imagery. Psychological Bulletin, 80, 1-24.

Manuscript received 10 September 1979.

Revised manuscript received 16 November 1980. 